\title{
An updated phytoplankton check-list for the Helgoland Roads time series station with eleven new records of diatoms and dinoflagellates
}

\author{
Alexandra Kraberg ${ }^{1^{*}} \mathbb{0}$, Ute Kieb ${ }^{1}$, Silvia Peters ${ }^{1}$ and Karen Helen Wiltshire ${ }^{1,2}$
}

\begin{abstract}
The Helgoland Roads time series is one of the longest and most detailed time series in the world. It comprises daily phytoplankton counts accompanied by physico-chemical measurements. As such, it provides valuable long-term record of changes and their underlying causes in the phytoplankton community around Helgoland. This work provides an updated check-list of the phytoplankton species encountered at the Helgoland Roads LTER station with additional taxonomic assessments from live net samples and scanning electron microscope surveys. Since the last check-list was published 11 additional taxa have been recorded for the first time comprising 9 diatom and 2 dinoflagellate species. Of the 9 diatom species 3 were Chaetoceros species: Chaetoceros anastomosans, C. pseudocurvisetus and C. Iorenzianus (the latter identified by their resting cysts) which were all first recognised in September 2009. The toxic dinoflagellate Dinophysis tripos, and the bipolar centric diatom Odontella longicruris both were first observed in September 2015. The latest new record is the potentially toxic dinoflagellate Alexandrium ostenfeldii, first recorded in August 2017. All of the first records (with the exception of Dinophysis tripos) were first observed in semi-quantitative surveys based on live samples and SEM demonstrating that adding less frequent but very detailed assessments can complement high frequency counts of fixed samples as long as these data of different origin are linked efficiently to the individual sampling event and all metadata including representative pictorial metadata are recorded in a consistent manner. In this manner the enhanced checklist serves as a baseline against which long-term changes in phytoplankton potentially related to ecosystem state can be addressed.
\end{abstract}

Keywords: Biodiversity, Helgoland transects, Helgoland Roads, New records, North Sea, Climate change, Long-term monitoring

\section{Background}

The Helgoland Roads long-term data series is one of the longest and richest biodiversity datasets in Europe [1]. Since its founding in 1962 it has provided a unique record of the long-term-changes in the phytoplankton community around Helgoland. Through concurrent measurements of inorganic nutrient concentrations and

\footnotetext{
${ }^{*}$ Correspondence: Alexandra.Kraberg@awi.de

${ }^{1}$ Alfred-Wegener-Institute Helmholtz Centre for Polar and Marine Research, Biologische Anstalt Helgoland, Kurpromenade 201,

27498 Helgoland, Germany

Full list of author information is available at the end of the article
}

physical parameters it provides the basis for the interpretation of phytoplankton occurrence (e.g. [2]. Much older semi-quantitative datasets are available as well [3]. The Helgoland Roads time series also has a high international standing with experts. Examples are the ICES expert group on phytoplankton and microbial ecology (http://wgpme.net), the IOC UNESCO TrendsPO Group for global phytoplankton analyses and within the German and European networks for long-term ecological research (LTER). The time series is also an important component of the Alfred-Wegener Institute's time series programme (https://www.awi.de/en/science/long-termobservations.html, http://data.awi.de). In addition to the 
Helgoland Roads LTER time series, three transects from Helgoland towards the Elbe and Eider estuaries and one transect into the open North Sea are also sampled from the RV Uthörn, on a monthly basis. The methodologies applied are the same as for Helgoland Roads (see below). Some information pertaining to these transects has also been used to further illustrate the new records described in this study.

Helgoland is located in a very dynamic hydrographic environment under the influence of varying regimes ranging from open North Sea conditions to more coastal conditions with reduced salinity $[4,5]$, which is particularly pronounced during periods of high river discharges from the river Elbe. This also contributes to a rich microalgal community but with considerable interannual variability. The species list for the Helgoland Roads LTER site is therefore extensive and requiring regular updates. However, as with most time series, for practical reasons, phytoplankton assessment is based on Lugol-fixed raw samples and consequently a large number of taxa usually remain unidentified to species level or rare species are missed because of the low volumes fixed. Lugol solution obscures taxonomic details (unless samples are destained e.g. with sodium thiosulphate) and can distort cell shapes [6]. Additional studies based on live and fixed net samples ( $20 \mu \mathrm{m}$ mesh size), collected regularly at Helgoland Roads (see below) were therefore also investigated and this data included in the check-list.

The last review of the community at Helgoland Roads was carried out in 2004 [7] (hereafter referred to as 'taxonomic check-list'). It was the first assessment of the Helgoland species complement since the check-list published by Drebes and Elbrächter in 1976 [8]. these earlier works were based mainly on observations of live cells from net hauls, scanning electron microscope imagery and cultures. Both laid emphasis on the dinoflagellates and diatoms as these are dominant taxon groups at Helgoland Roads. The taxonomic check-list published in 2004 revealed 227 taxa in total including 132 diatom species (from 53 genera) and 95 species of dinoflagellates (from 35 genera). Of these 35 diatom taxa and 28 dinoflagellate taxa were new records for Helgoland Roads.

The taxonomic check-list was produced 15 years ago and in the meantime a number of additional species have been recorded and thus, this paper represents an update on the species pool at Helgoland Roads. In the course of this new examination of phytoplankton species at Helgoland Roads the taxonomic check-list was also incorporated into the current taxon list (hereafter referred to as the 'LTER list') used for the routine quantitative phytoplankton counts (based on counts of Lugol-fixed samples) at the Helgoland Roads LTER site. By combining the two lists we hope to provide one baseline for future investigations of species composition at Helgoland Roads that can be expanded and annotated in a consistent manner as new records are found. Future updates might also include molecular data but for the present study we concentrated on methodologies similar to those in the older studies.

\section{Methods}

Surface water samples for routine quantitative phytoplankton counts at the Helgoland Roads LTER site (54.188330N, 7.9E) (Fig. 1) were collected work-daily, using a bucket. The sample was mixed well before a $100 \mathrm{ml}$ subsample was preserved in $0.1 \%$ neutral Lugol's iodine and stored in an amber glass bottle. Before $25 \mathrm{ml}$ was analysed using the Utermöhl method [9]. In addition to the bucket samples, net samples are taken twice a week (mesh sizes 20 and $80 \mu \mathrm{m}$ ). Samples were fixed in Hexamine-buffered Formalin (4\%) and stored in $30 \mathrm{ml}$ brown glass bottles [10]. Due to time constraints the latter samples are not analysed routinely (i.e. twice a week year round) but are used to complement the Lugol counts and are analysed more extensively whenever time permits. For the present study a total of $12120 \mu \mathrm{m}$ net samples were considered and were analysed prior to fixation to investigate community composition on the basis of live plankton. The earliest sample considered dates back to 2009 but the majority of samples were analysed between 2015 and 2018. The $20 \mu \mathrm{m}$ net samples were examined live using an Axiovert 2 microscope at a magnification of $\times 200$ and 400 . Photographs were also taken at a magnification of $\times 400$ with the exception of a small number of large species, which were at $\times 200$ or less. Although

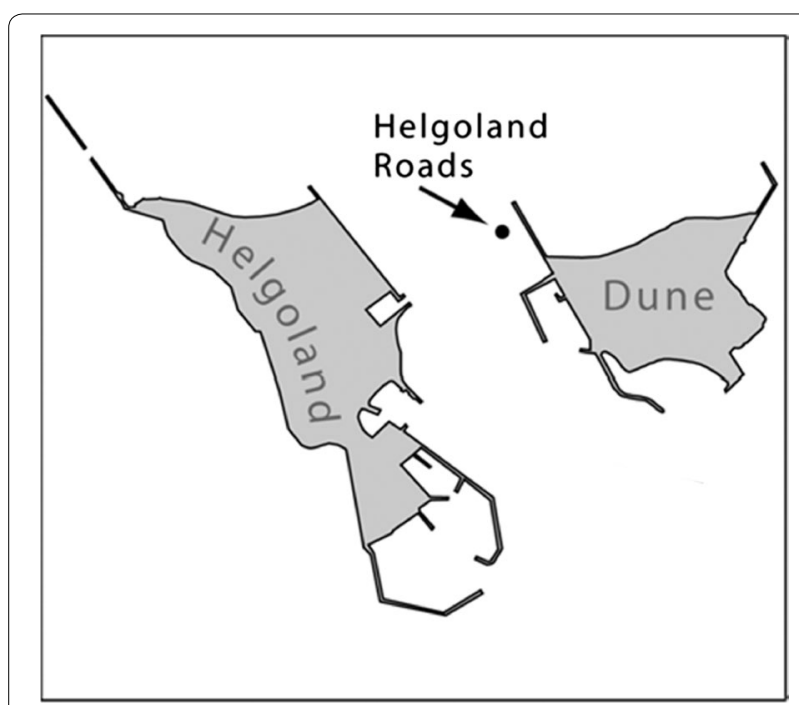

Fig. 1 Helgoland Roads Sampling location between the main island of Helgoland and the Düne island 
these investigations are not quantitative, sampling effort was controlled by always assessing two microscope slides under a $20 \times 60 \mathrm{~mm}$ cover slip. Despite the irregular analysis frequencies these samples are useful for taxonomic assessments but it has to be noted that it is not possible to infer any temporal dynamics from the with respect to the appearance or appearance of species at the site. For detailed taxonomic analyses (the main goal being to identify as many taxa as possible to species level) 20 of the Formalin-fixed $20 \mu \mathrm{m}$ net samples were used for electron microscopic analyses and additionally original descriptions and other taxonomic literature available in peerreviewed publications were consulted.

\section{Electron microscopy}

Electron microscopy was carried out on selected samples to provide additional confirmation for species identifications or to elucidate the identity of organisms. Preparations for Scanning electron microscopy (SEM) were made from $20 \mu \mathrm{m}$ net hauls originally fixed in $4 \% \mathrm{Hex}$ amine buffered Formalin. Each sample was centrifuged 4-5 times at $2000 \mathrm{rpm}$ for $5 \mathrm{~min}$, each time removing the supernatant and replacing it with distilled water [11]. When a small pellet had formed, this was transferred to brown glass bottles and fixed with absolute alcohol. In addition to these uncleaned samples, a second fraction of the same sample was first acid cleaned to better reveal the structure of the diatom frustules following the method of [11]. For transmission electron microscopy (TEM) Formalin-fixed net samples were used. TEM studies were used mainly to investigate the Pseudo-nitzschia species at Helgoland Roads which are not identifiable using light or scanning electron microscopy. These were prepared following the methods described in Lundholm et al. [12]. For more details see also [13]. The present work did not include analyses of molecular data sets.

\section{Data treatment and archival}

To assess the full complement of species recorded at Helgoland Roads to date (irrespective of whether they were detected by full microscope counts, scanning electron microscopy or observation of live material, the taxonomic check-list of 2004 was compared and combined with species reported in the Helgoland Roads LTER list. The latter is a record of all taxa identified during the routine daily quantitative counts using the Utermöhl method. As this list is based on Utermöhl counts, it is less taxonomically extensive than the taxonomic check-list. We paid special attention to the use of multiple names for the same taxon that could artificially inflate the number of species in the combined list. As name changes and reported name ambiguities were numerous, the names reported in the taxonomic check-list were given preference (e.g.
Rhizosolenia robusta in the LTER list vs Calyptrella robusta in the taxonomic check-list). The goal of producing a combined list was simply to produce a record of taxa that have previously been recorded (by whatever method), but explicitly not to investigate species fluxes i.e. immigration into the system or local extinction.

In some cases, species names occurred exclusively in the Helgoland Roads species list. As no image material accompanied some of these older records, it was not always clear whether they really referred to a distinct species or were used as a proxy for certain groups (e.g. Pseudo-nitzschia seriata for all Pseudo-nitzschia cells with a diameter exceeding $3 \mu \mathrm{m}$ ) they were kept in the combined list (Table 1).

The names in the taxonomic check-list and the LTER list were checked against entries in the World Register of Marine Species (http://marinespecies.org, [14]). All numerical data underlying this work are archived in the online data repository Pangaea (http://www.panga ea.de). Each annual data set in Pangaea is annotated with the WORMS Aphia ID, so that for each individual Pangaea species record, formal taxonomic data can also be accessed. In addition, reference images have been archived in the image repository PLANKTON*NET (http://planktonnet.awi.de). These are, where relevant, also linked back to the data sets in Pangaea (see example in https://doi.pangaea.de/10.1594/PANGAEA.86290 6). The raw data are accompanied by a locally stored metadata file, in which unusual weather phenomena, and methodological issues affecting the samples are recorded. Since 2015, a metadata archive for new taxa at Helgoland Roads has also been maintained. This records the date and place of first occurrence (Helgoland Roads or Helgoland transects), the type of sample the organism was encountered in, as well as photographic documentation of the observed taxon [15].

\section{Results}

Two species lists were previously generated for Helgoland Roads, the taxonomic species list [7] and the LTER list for the actual Helgoland Roads quantitative counts. Prior to the present work the LTER list that forms the basis for the Helgoland phytoplankton counts, contained 261 entries with 84 distinct diatom and 41 dinoflagellate species recognized (with entries of size classes for taxa not identified to species level constituting the remainder. After incorporating the taxa recorded in [7] and the new finds described here, while also considering species mentioned in both lists, results in a total species list of 250 distinct species, with 147 diatom and 97 dinoflagellate taxa and additionally, three silicoflagellates, two ciliate species and one named chlorophyte species resulting in a total of 250 species (Table 1 ). 


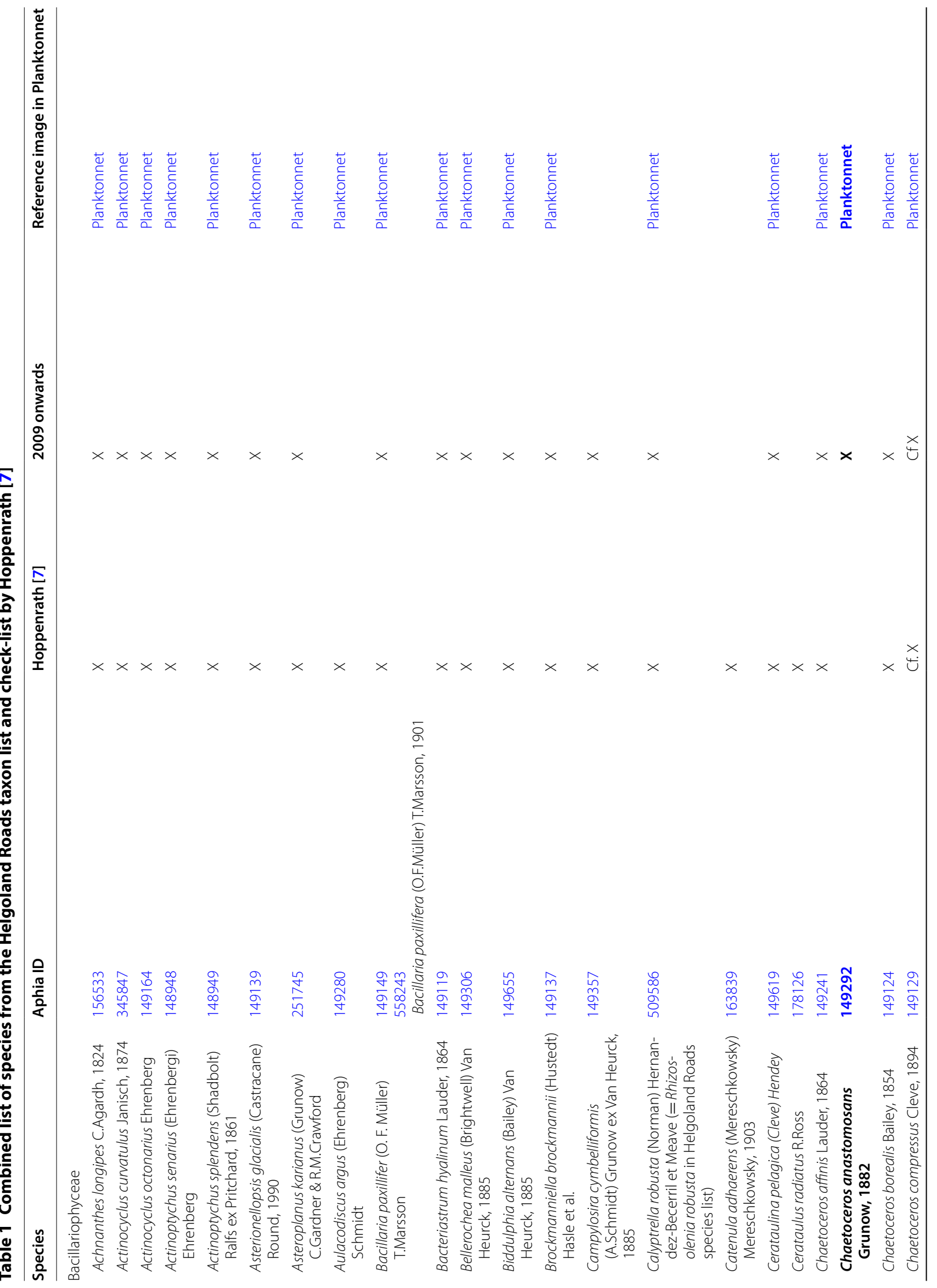




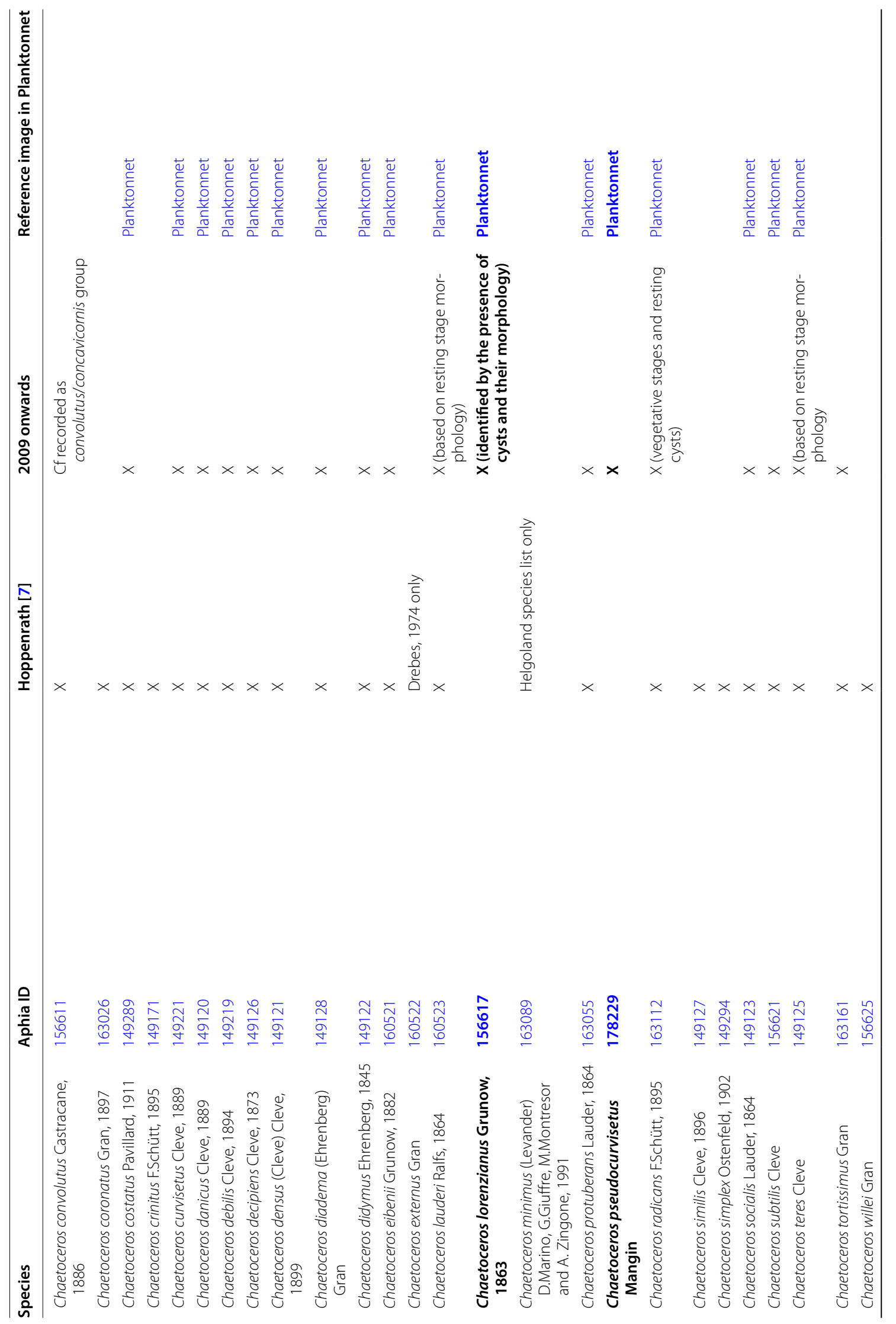




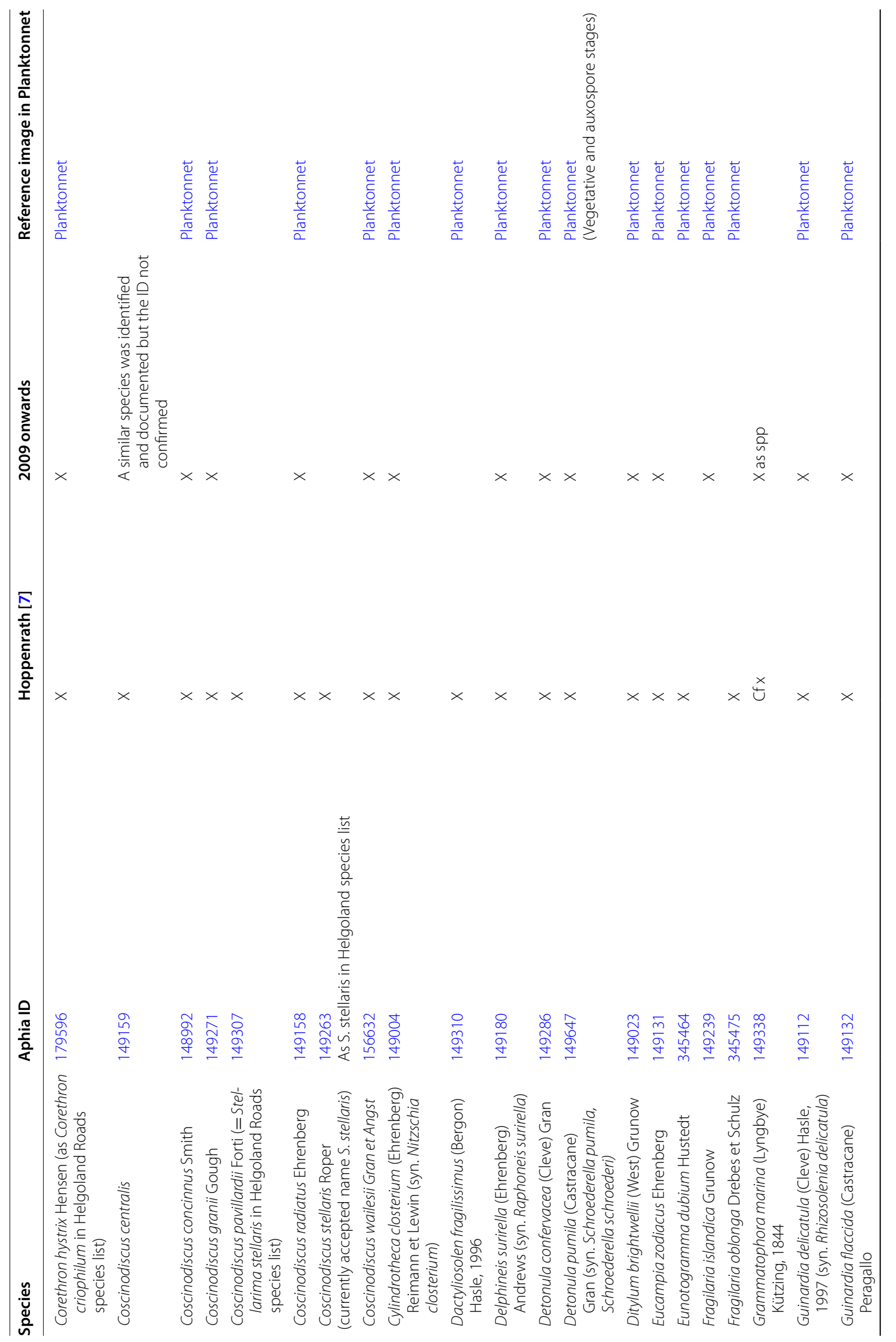




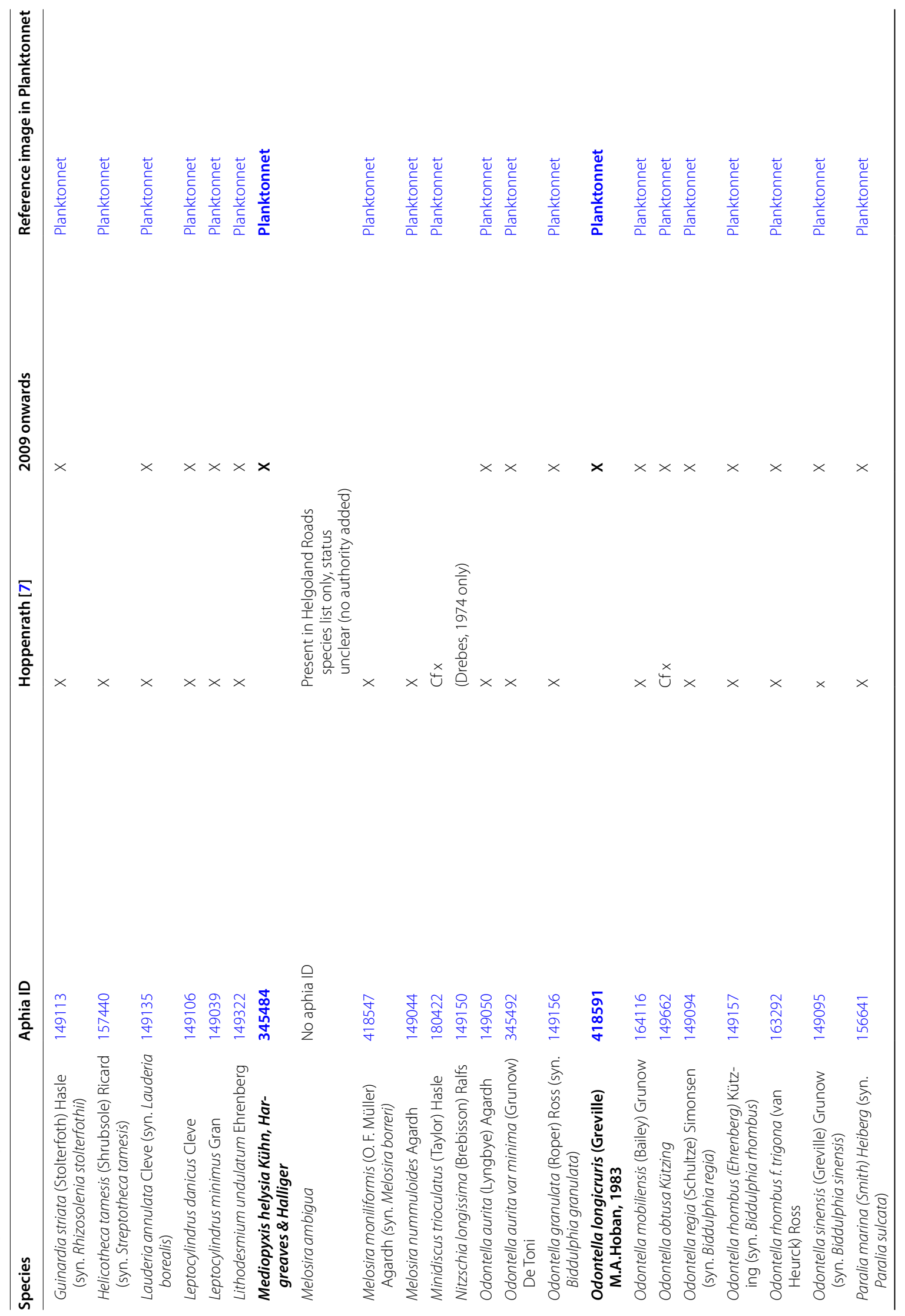




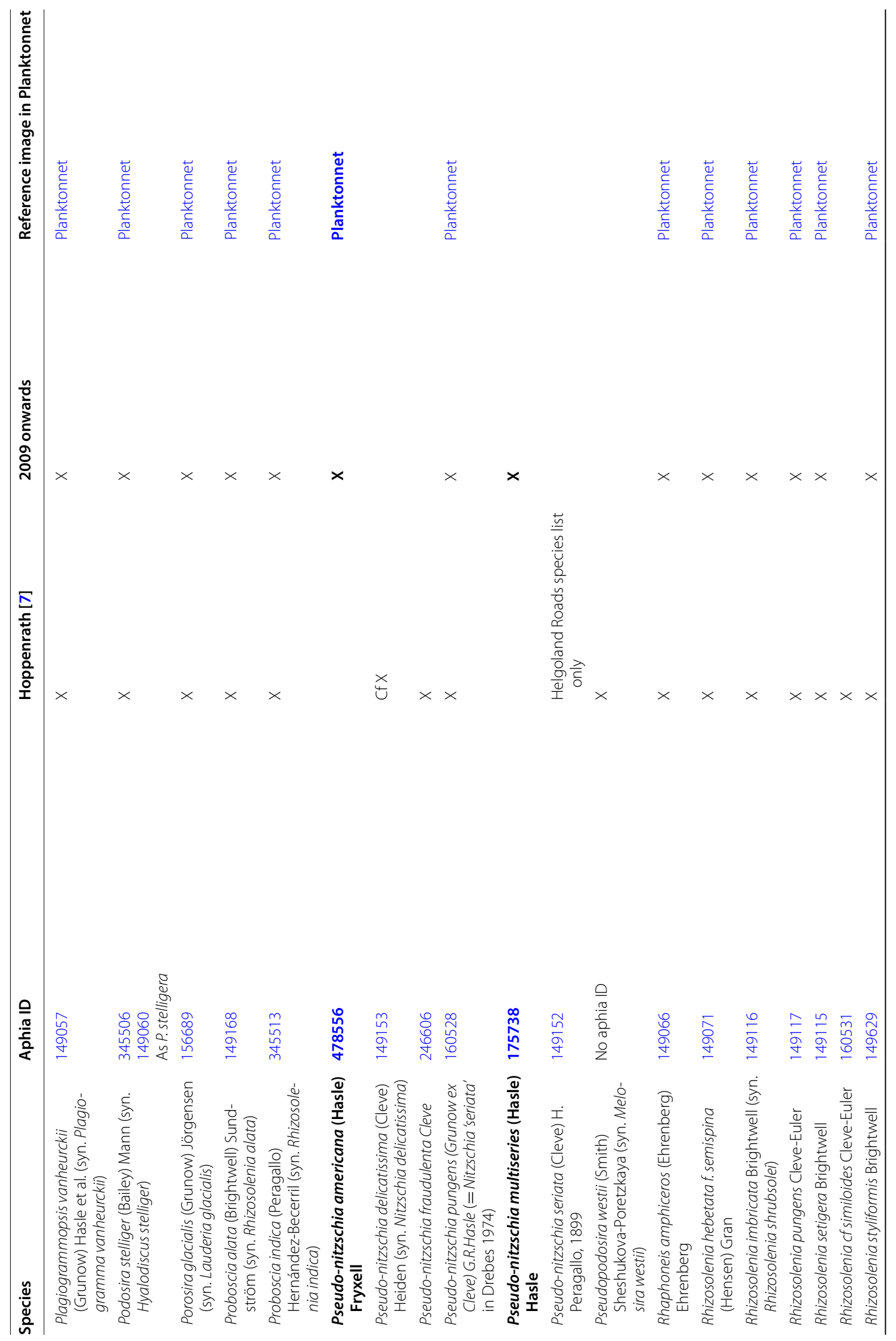




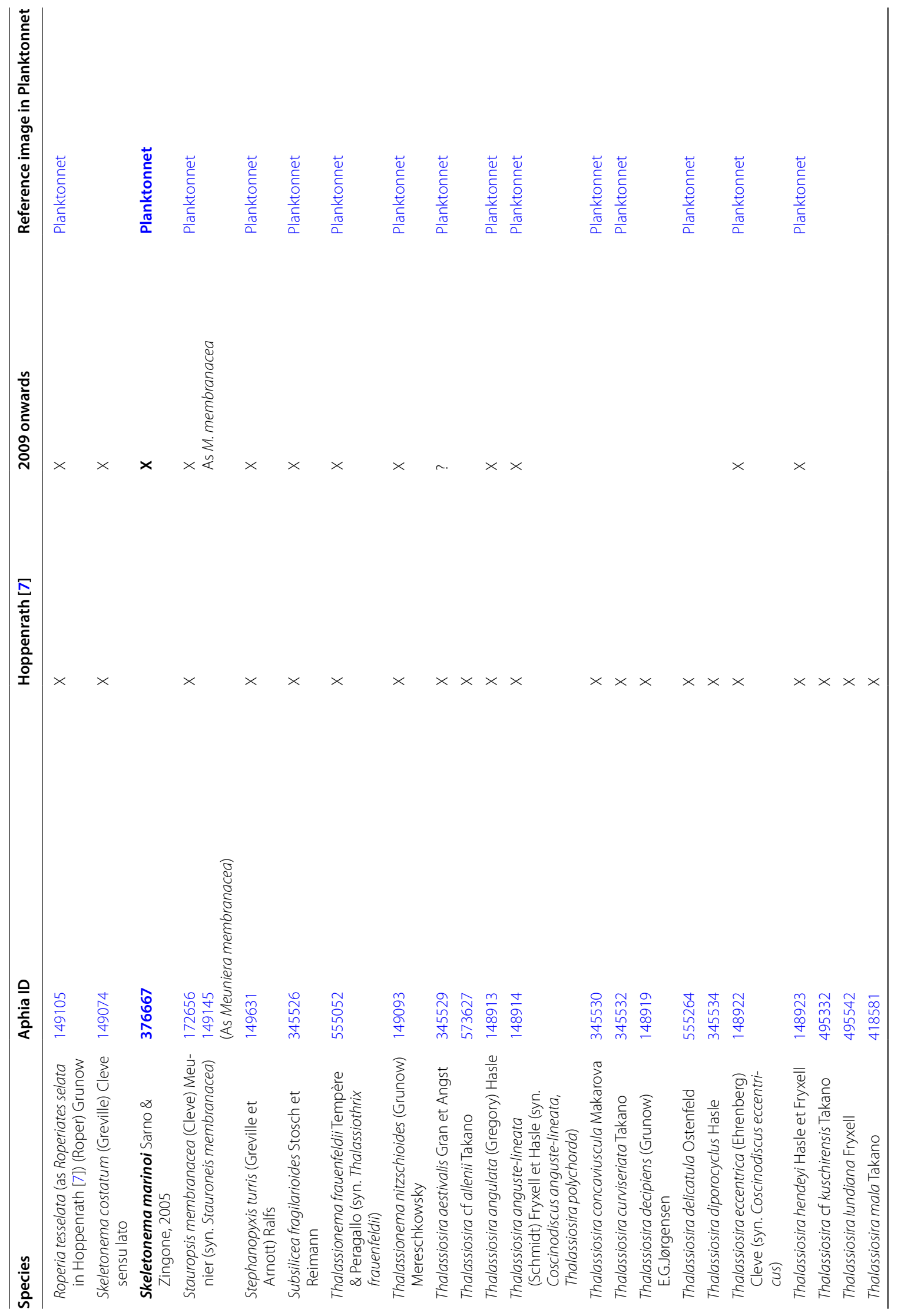




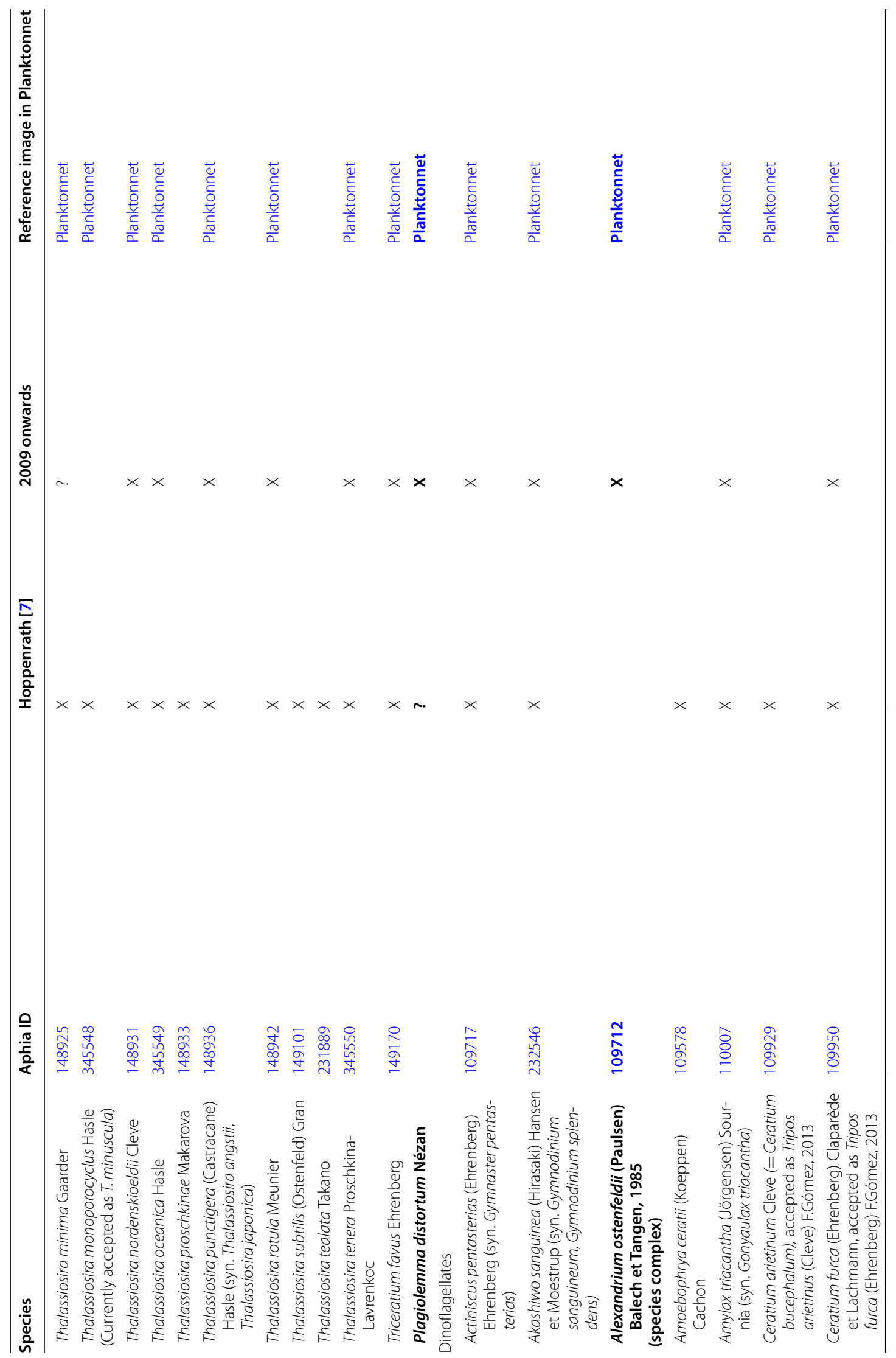




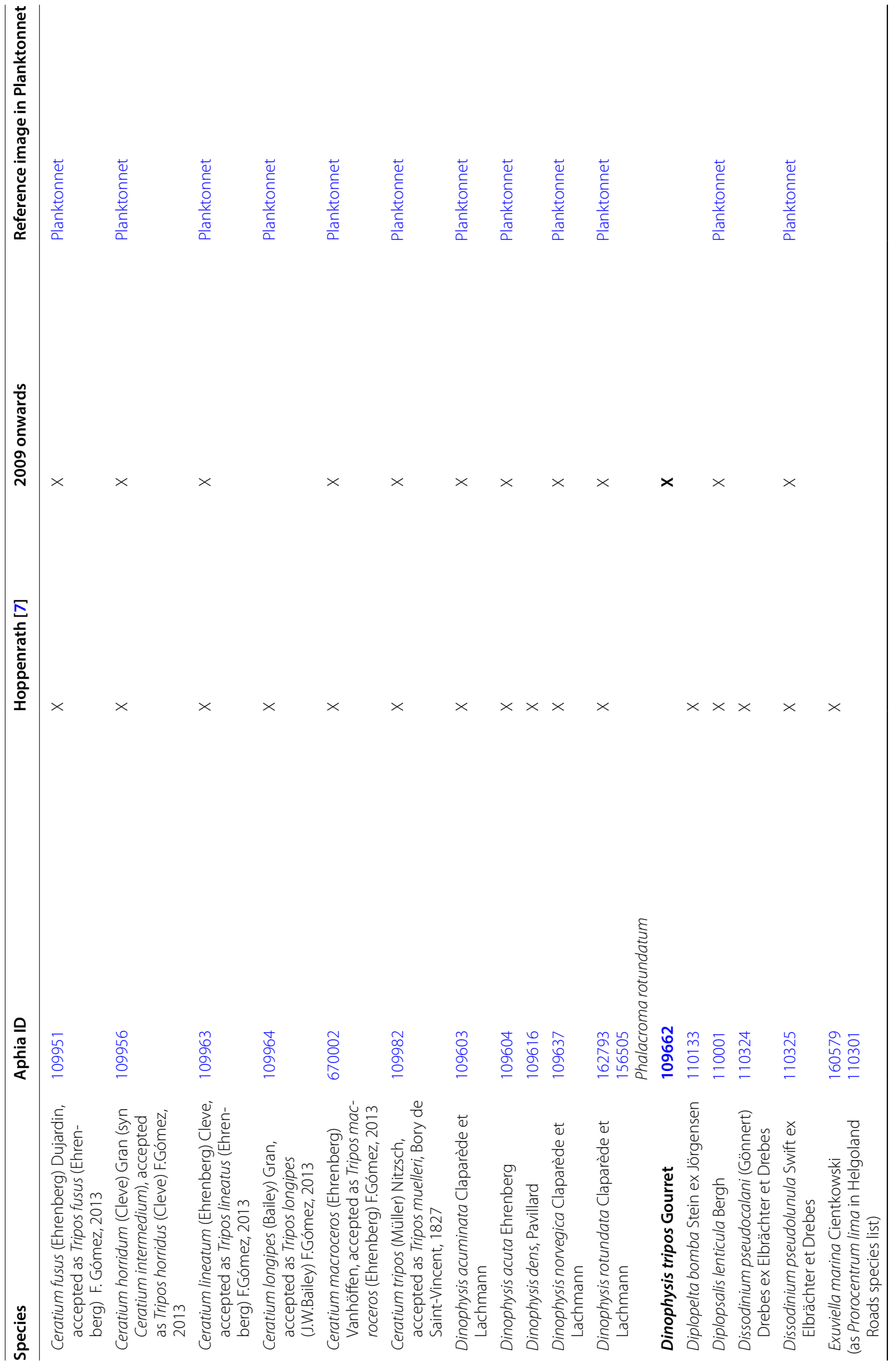




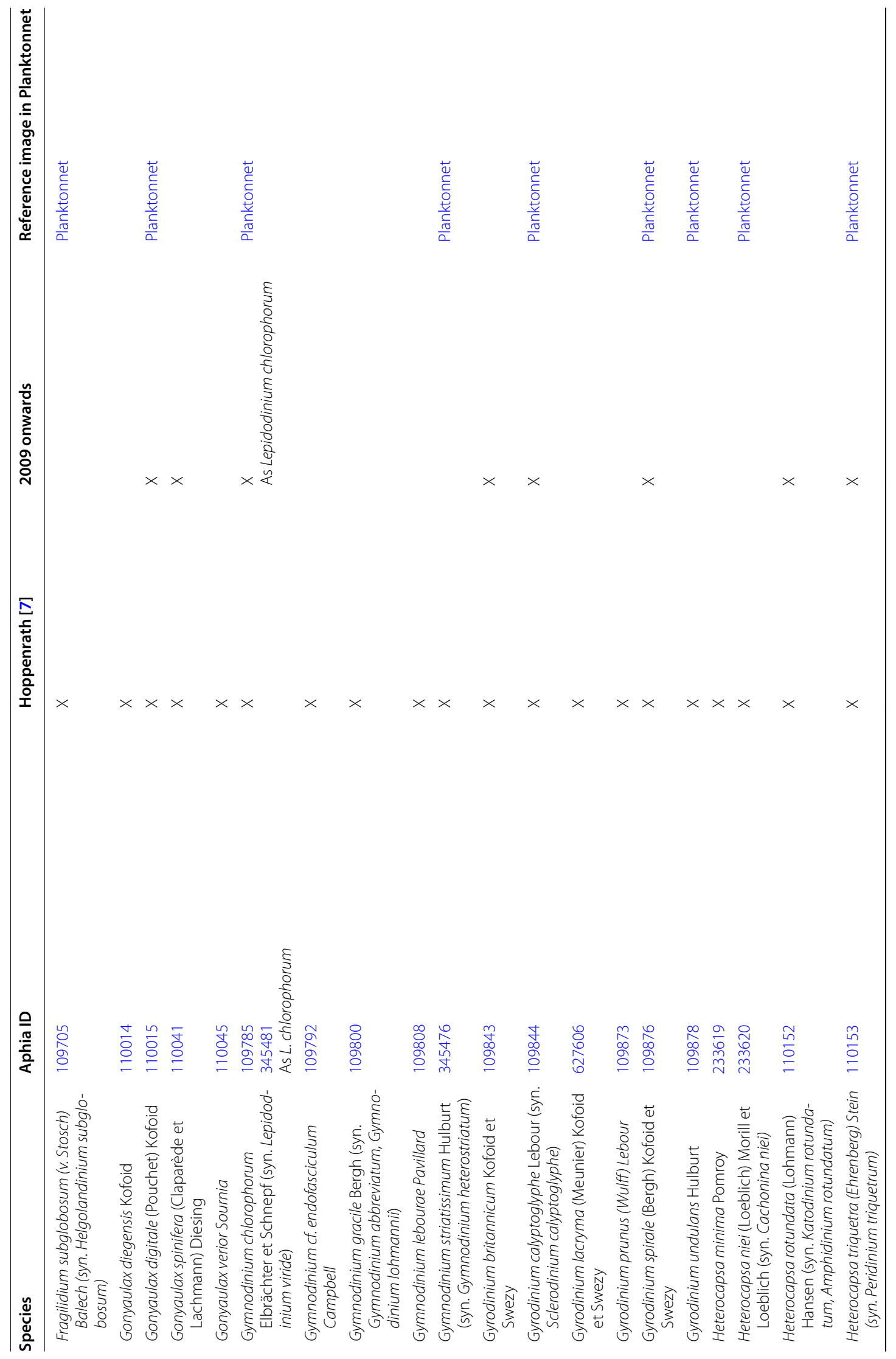




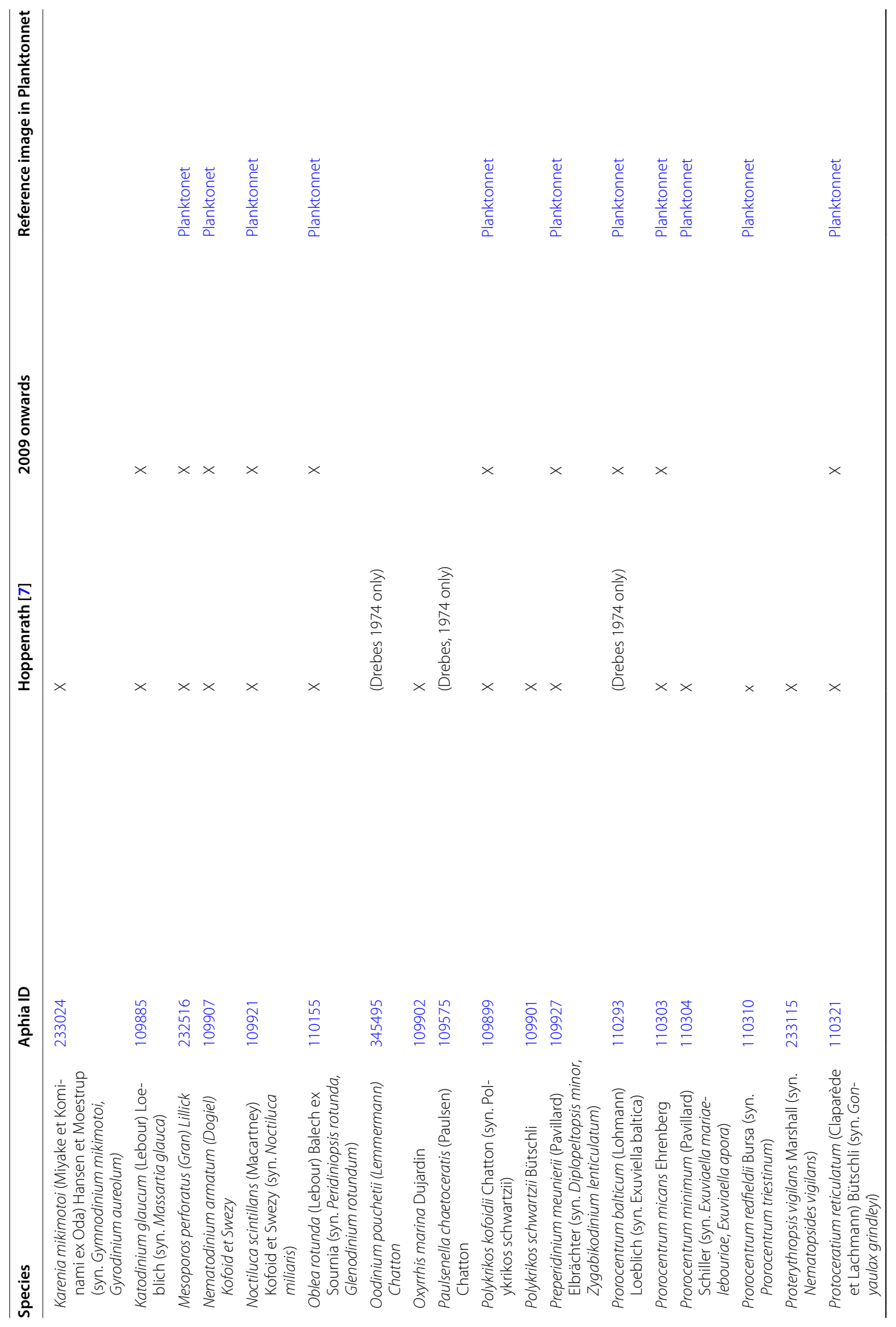




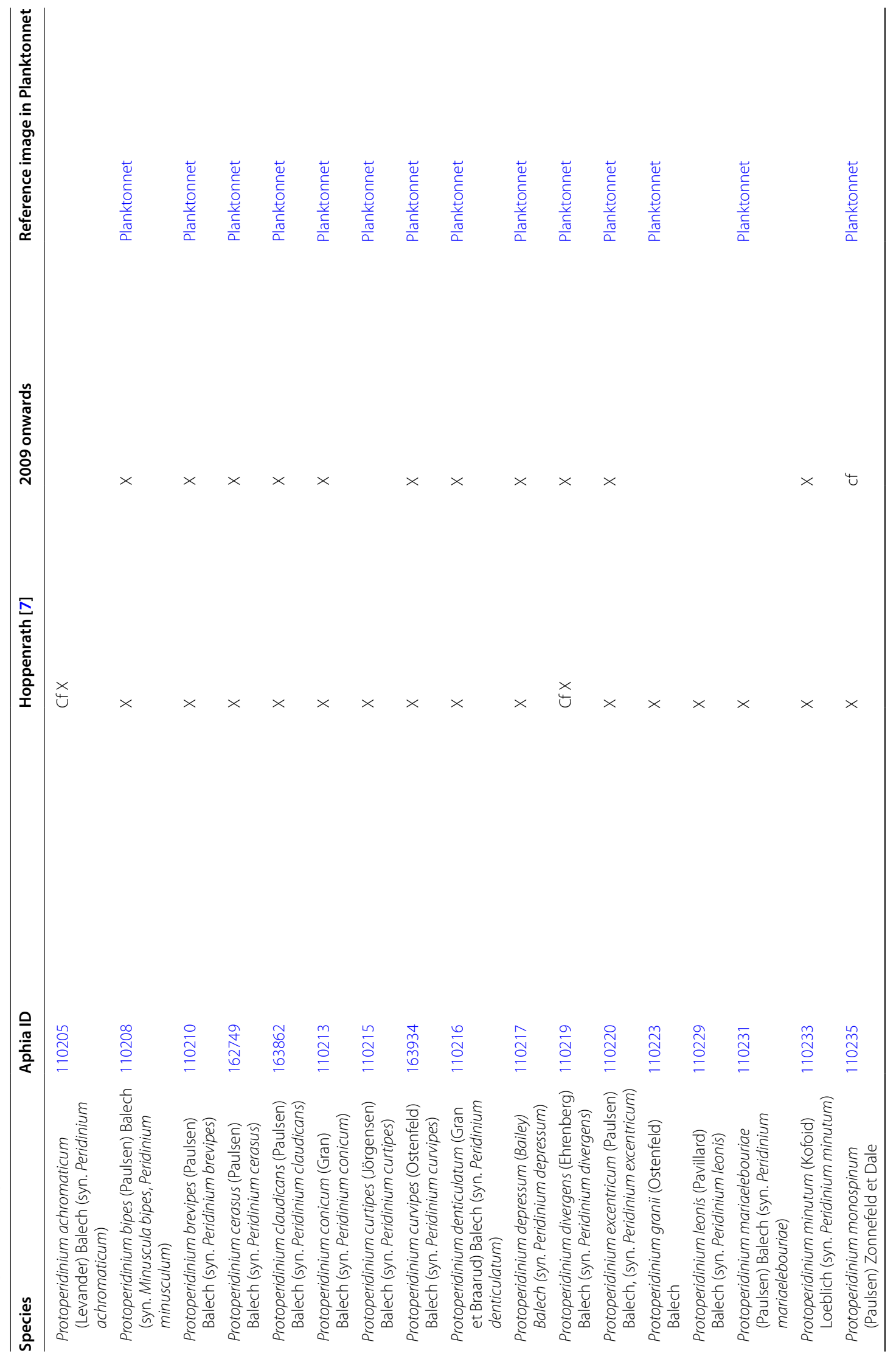




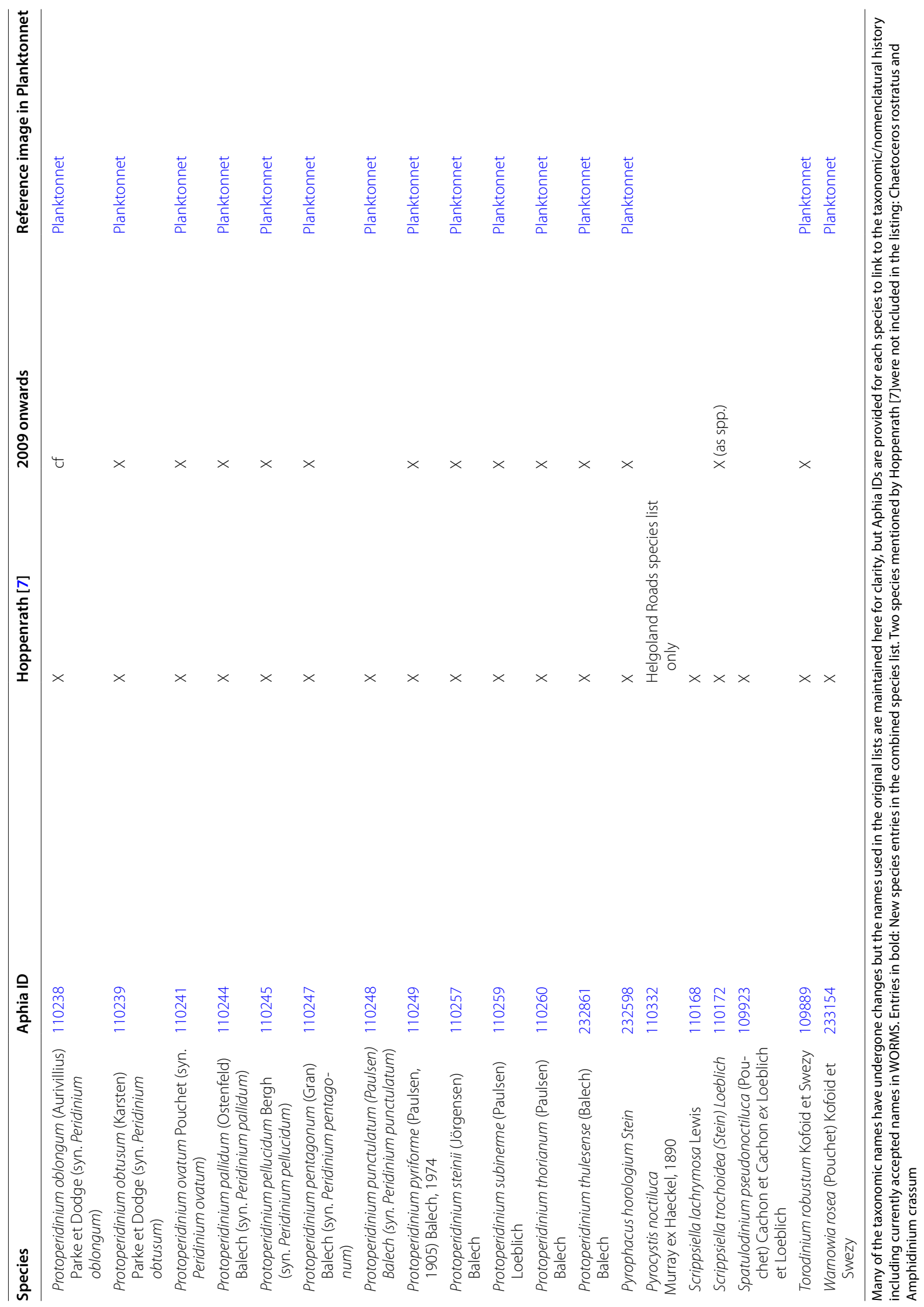


Below we report 11 new records, nine for diatoms and two for dinoflagellate species. We also include information on the environmental conditions for when they were first recorded (Table 2).

\section{Diatoms}

\section{Chaetoceros species (Fig. 2a, $b$ and $i$ )}

Since 2004 three new records of Chaetoceros species have been confirmed. Chaetoceros pseudocurvisetus Mangin, 1910 was first detected in two net samples (September 24th and September 29th 2009) and since then on October 14th 2014 (Fig. 2a). Chaetoceros anostomosans Grunow, 1882 was first observed in a $20 \mu \mathrm{m}$ net sample from September 24th 2009 (Fig. 2b). This sample was very diverse with a total number of 66 identified taxa. Chaetoceros anastomosans is a very distinctive species. The setae of adjacent cells are only linked at a distance away from the valve margin by silica bridges running parallel to the chain axis. Only one chain was observed in the sample of September 24th and no cells were found during the SEM surveys. Therefore, we only show light micrographs. due to the distinctness of the diagnostic features as the taxon was identified as Chaetoceros anastomosans based on light micrographs alone. After the first record in 2009 it was not recorded again until July 2017 and then June 2018 on less than 10 occasions in total. Chaetoceros lorenzianus Grunow, 1863 was recorded on several occasions. A pair of cells forming resting stages was observed (Fig. 2i), thereby confirming its identity. C. lorenzianus has a very similar morphology to $C$. decipiens but can be distinguished by the formation of resting cysts, which have not yet been observed in Chaetoceros decipiens Cleve, 1873. This species was recorded again in several samples in September 2010 and was also abundant in September 2016.
Odontella longicruris (Greville) M.A.Hoban, 1983 (Fig. 3a-c) Odontella longicruris was first observed September 27th 2016. It is a bipolar centric diatom, which has a characteristic cell outline in broad girdle view. The valve face is strongly convex in the centre forming a clearly visible elevation bearing two prominent spines arising from the central valve face in close proximity before diverging. The aperture is therefore typically panduriform [16]. Odontella longicruris is sometimes considered a warm water species [17], but has actually a very broad (but not cosmopolitan) distribution. It has been reported mostly from coastal areas in the Pacific (both North and South America and also from Asia e.g. Japan and along the Argentinian coast) [18]. Our searches in both the Ocean Biogeographic information system (OBIS) and the Global Biodiversity Information Facility (GBIF) did not reveal any records of this species for the North Atlantic in general and specifically for the North Sea (https://www.gbif. org/species/5421683, http://www.iobis.org/mapper/, sites accessed January 16th, 2019). If this is indeed the only (or one of very few possibly unreported) occurrences of this species in the North Sea, it seems likely that this is a recent introduction to the area (although the vector of transport is entirely unclear). However, what may be more interesting is the question of whether $O$. longicruris is likely to establish as a regular phytoplankton component. Considering that we have now seen records of this species for over 2 years, albeit in low numbers, indicates that this species might not just be a transient feature of the Helgoland.

\section{Mediopyxis helysia Kühn, Hargreaves and Halliger, 2006} (Fig. 2c)

This is a large bipolar centric diatom species (apical diameter up to $100 \mu \mathrm{m}$ first recorded from the Gulf of Maine and the island of Sylt, see also [19]). It was first recorded at the Helgoland Roads site in March 2009 [20].

Table 2 Environmental parameters at the time of detection of new taxa at Helgoland Roads, excluding species that were confirmed on the basis of REM/TEM but for which the date of the first record is unclear

\begin{tabular}{|c|c|c|c|c|c|}
\hline Species & Detection date & Temperature & Salinity & $\begin{array}{l}\text { Total number } \\
\text { of sightings }\end{array}$ & Sample type \\
\hline Mediopyxis helysia & 20.03.2009 & 4.4 & 29.194 & $>100$ & $\begin{array}{l}\text { Quantitative/ } \\
\text { Semi-quanti- } \\
\text { tative }\end{array}$ \\
\hline Chaetoceros anastomosans & 24.09.2009 & 16.7 & 32.938 & $<10$ & Semi-quantitative \\
\hline Chaetoceros lorenzianus & 24.09.2009 & 16.7 & 32.938 & $<10$ & Semi-quantitative \\
\hline Chaetoceros pseudocurvisetus & 29.09.2009 & 16.5 & 32.514 & $>10$ & Semi-quantitative \\
\hline Dinophysis tripos & 13.08.2014 & 18.2 & 33.310 & 1 & Quantitative \\
\hline Odontella longicruris & $\begin{array}{l}06.10 .2015 \\
27.9 .2016\end{array}$ & $\begin{array}{l}15.9 \\
16.5\end{array}$ & $\begin{array}{l}33.394 \\
32.49\end{array}$ & $<10$ & $\begin{array}{l}\text { Quantitative } \\
\text { Semi-quantitative }\end{array}$ \\
\hline Alexandrium ostenfeldii & 8.8.2017 & 17.8 & 32.53 & $<10$ & Semi-quantitative \\
\hline
\end{tabular}




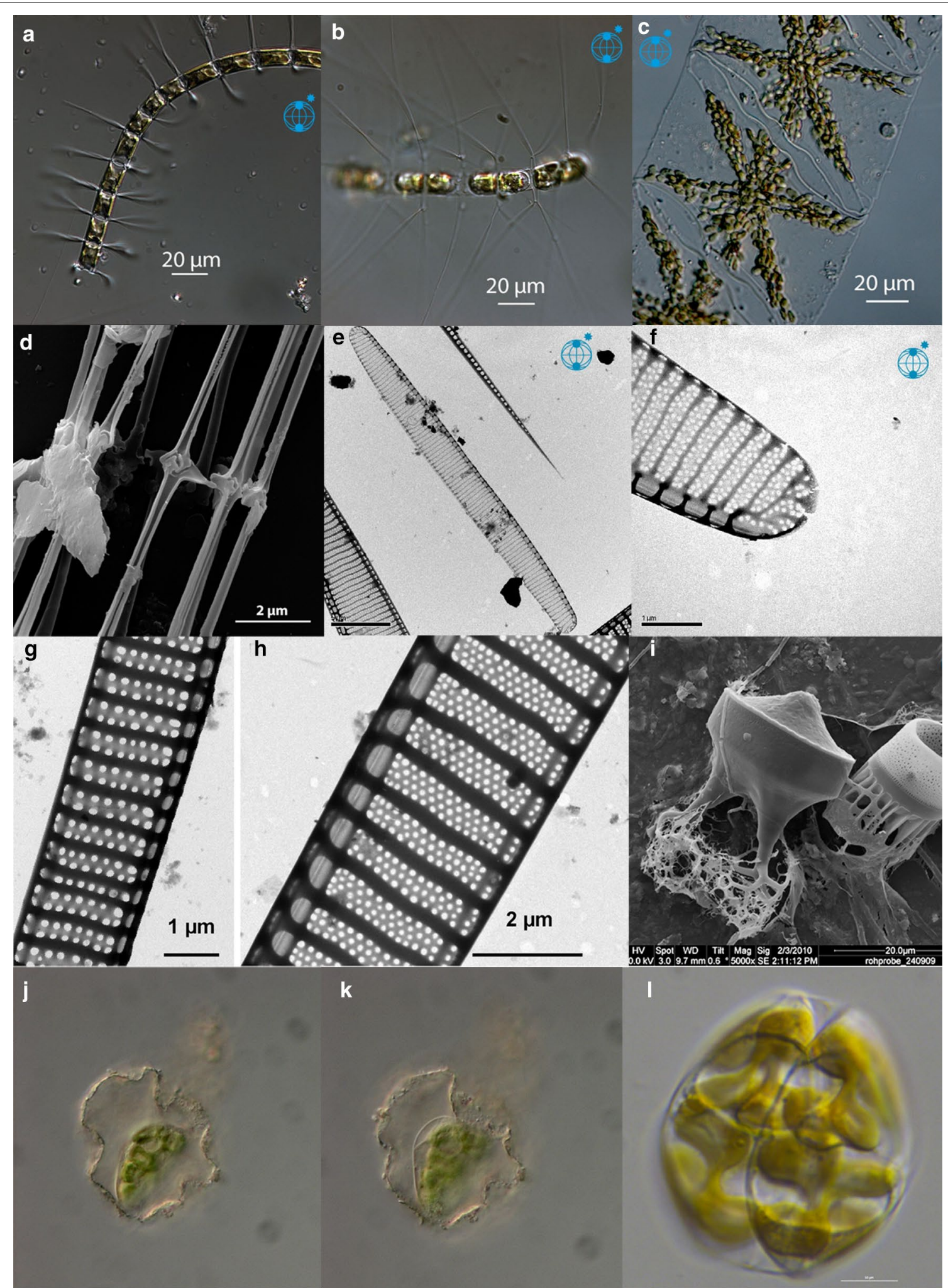

Fig. 2 a-j Images documenting the new taxon records at the Helgoland Roads Long-term monitoring station since 2004: a Chaetoceros pseudocurvisetus, b Chaetoceros anastomosans, c Mediopyxis helysia, $\mathbf{d}$ Skeletonema marinoi/dohrniii, e, $\mathbf{f}$ Pseudo-nitzschia americana, $\mathbf{g}, \mathbf{h}$ Pseudo-nitzschia multiseries, i Chaetoceros Iorenzianus, as identified by their cyst stages, j, I Plagiolemma distortum (Image L author: Dr Claire Widdicombe: http://planktonnet.awi.de/index.php?contenttype=image_details\&itemid=66958\#content) 


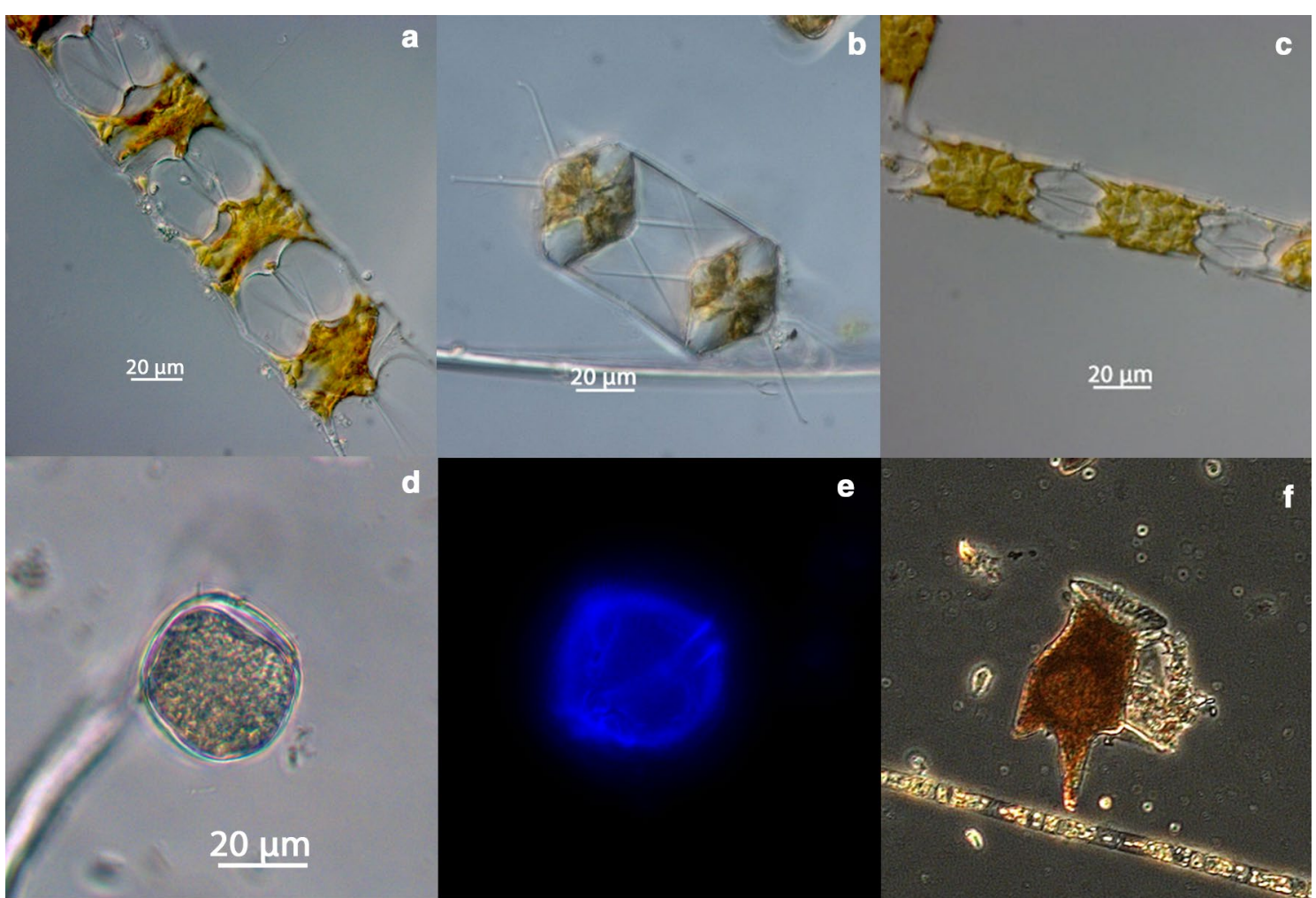

Fig. 3 a-e Examples of new records (continued): a-c Morphological variants of the bipolar centric diatom Odontella longicruris (two sampling dates: a, c September 27th, 2016, b August 24th, 2017), d, e the toxic dinoflagellate Alexandrium ostenfeldii (d live cell, b calcofluor-stained cell), $\mathbf{f}$ the toxic thecate dinoflagellate Dinophysis tripos

The species has characteristic star-shaped chloroplasts and the valve outline, which has one rounded and one pointed valve apex, is also diagnostic. An earlier study reported that this species was first observed in 2003 [21], but it was not observed during the routine phytoplankton counts on Lugol samples, and did not appear in the 2004 check-list. Mediopyxis helysia formed extensive blooms in Helgoland Roads in 2010 (and also in the Dutch Wadden Sea [22], but appears to be restricted to quite specific environmental conditions occurring predominantly during periods with reduced salinities [20] and its numeric importance appears to be diminishing again at least at Helgoland Roads.

\section{First records for diatoms only identifiable using advanced microscopy e.g. electron microscopy}

a. Pseudo-nitzschia species The combined check-list also includes three new records of species that are likely to have been occurring at Helgoland Roads previously, but that could not be confirmed (and therefore not be enumerated during routine monitoring) without detailed SEM and TEM studies. These include Pseudo-nitzschia americana (Fig. 2e, f) and Pseudo-nitzschia multiseries
(Fig. 2g, h) [13]. Both Pseudo-nitzschia species require TEM for reliable identification. They are identified based on their valve morphology particularly the number of striae, number of poroid rows in the interstriae and the number of fibulae. In Pseudo-nitzschia multiseries there are 3-4 poroid rows, each with 4-6 poroids in $1 \mu \mathrm{m}$ [23]. Pseudo-nitzschia americana cells on the other hand are linear to slightly lanceolate in valve view and have broadly rounded valve ends. [12, 24, 25]. For the Helgoland Roads LTER site these two new records have been added to the species list, but due to the methodological constraints mentioned, they cannot be counted at species level. The Helgoland Roads species list also mentions two further species, Pseudo-nitzschia seriata (as a proxy for species with a diameter exceeding $3 \mu \mathrm{m}$ ) and Pseudo-nitzschia delicatissima. While true $P$. seriata has, to our knowledge, not actually been observed in Helgoland as yet, $P$. delicatissima has. However, as both names were used in the past they were retained in the species list. With a diameter of 2.5-4 $\mu \mathrm{m}$, the latter taxon could have been included in the counts for either of the two Pseudo-nitzschia size classes, or, due to their somewhat atypical morphology, have been counted as an unidentified pennate diatom. 
Since both $P$. multiseries and $P$. americana are known to be toxic, and broadly distributed [26], attempts should be made to identify them in future studies, with targeted molecular studies but accompanied by microscopy.

b. Skeletonema marinoi Sarno and Zingone, 2005 (Fig. 3d) [27, 28] Skeletonema marinoi has probably been identified as $S$. costatum sensu lato previously. This species was not identified in the routine Lugol samples but in scanning and transmission electron micrographs (S. marinoi). Skeletonema costatum was previously thought to be a cosmopolitan species. However, a considerable number of new species have now been described and some of these have quite distinct species distributions [29]. It is now clear that the taxon named Skeletonema costatum, based on type material, actually has quite a limited distribution and does probably not occur in most areas from which it has reported. Based on available samples, it actually seems to be restricted to a small number of locations in North and South America (Florida, Patos Lagoon in Brazil, Uruguay) and the Taiwan Strait. The species in Helgoland is in fact S. marinoi which has been reported from a large number of locations, including the Adriatic and Baltic [30], the Dutch Coast and English Channel [29] and the Atlantic Coast of North and South America (and one record from Peru). However, as this species is probably consistently mis-identified in time series around the world, it is difficult to really assess its distributional history from data relying on the routine microscope counts. More detailed molecular analyses would be necessary here.

\section{Plagiolemma distortum Nézan (Fig. 2j-l)}

The first record of this species at Helgoland Roads was on November 2nd 2016 and in Elbe transect station 6 (on July 7 th 2016). This is a pennate diatom with a sigmoid raphe. Cells typically have an elliptical shape in girdle view and lobed chloroplasts. Cells are motile and sometimes found within a mucilage envelope (Fig. $2 j-1$ ). The identity of this taxon was unresolved until recently. However, based on our image material and live observations of the taxon's motility (Kraberg pers obs) the taxon has now been assigned to the recently described diatom Plagiolemma distortum [31]. The taxon has been reported from a number of localities in the German Bight and English Channel (e.g. at time series station L4 run by the Plymouth Marine Laboratory). The northern-most record was located at the island of Sylt, see the summary in [32] The taxon has been documented by image material since the early 1990s, which allowed the collation of a distribution history including data from long before the taxon was named [32]. Interestingly while its occurrence has now been confirmed in a number of locations in the southern North Sea and English Channel, all the early sightings were recorded from brackish waters with a broadening of the distributional range in a northerly direction and towards the English Channel occurring after 2013 and being recorded at L4 in November 2015 initially [32]. However, whether this is a true range extension or the result of a greater availability of georeferenced image material is not at all clear and requires further investigation.

\section{Dinoflagellates \\ Dinophysis tripos Gourret, 1883 (Fig. 3f)}

This species was first observed at Helgoland Roads in 2014. In addition to Helgoland Roads it has also been found at station Elbe 1 (54.151700N, 7.891700E) of the monthly Helgoland transect surveys. This is a large and conspicuous species with two pronounced antapical protrusions (in contrast to Dinophysis caudata Saville-Kent, 1881 which has only one such protrusion). Dinophysis tripos is considered to be a warm-water species [33] with only 4 records from the North Sea according to OBIS (http://iobis.org/explore/\#/taxon/434520, search carried out on January 10th 2017). But it has also been observed in the Skagerrak (http://nordicmicroalgae.org/taxon /Dinophysis\%20tripos?media_id=Dinophysis\%20tri pos_6.jpg, search carried out on January 15th 2019).

\section{Alexandrium ostenfeldii (species complex, Fig. 3d, e)}

This toxic thecate dinoflagellate was first confirmed August 8th 2017, although since it is difficult to identify by light microscopy only, it might easily have been overlooked previously. Cells were first detected in light microscopy with differential interference contrast (DIC). They were confirmed after staining with Calcofluor and epifluorescence microscopy, which revealed the teardrop-shaped apical pore complex and the angular first apical plate with its large pore, the latter facilitating identification as Alexandrium ostenfeldii (species complex). This species is a potential producer of spirolides [34].

$A$. ostenfeldii has a broad geographical distribution with blooms frequently occurring in the Baltic [30] and also the Gulf of Maine [35]. It has also already been reported from the Northern North Sea [36]. From the records collected so far, this seems to be a predominantly coastal species.

\section{Discussion}

Several check-lists have previously been produced for the phytoplankton community around the island of Helgoland $[7,8]$. Since the last comprehensive list in 2004 (taxonomic checklist) [7] 11 new taxa have been observed in Helgoland Roads, in some cases backed up with additional records from the Helgoland transect surveys. 
These new records fall into two categories: (1) those identified from routine counts of Lugol-fixed samples or semi-quantitative assessments of live and preserved net samples, and (2) those resulting from occasional intensive surveys using additional microscopy techniques (SEM, TEM and epifluorescence microscopy (e.g. for confirmation of Alexandrium ostenfeldii)). The counts for the long-term monitoring at the LTER site Helgoland Roads are based on Lugol-fixed samples and therefore many phytoplankton species are not identified to species level. Hence, it is not surprising that it required additional studies, using scanning or transmission electron microscopy or live net samples, to confirm some of the new records. As these surveys are not feasible on a regular basis, new records based on such surveys can therefore not necessarily be interpreted as a sign of changing environmental conditions. This is the case for the two new Pseudo-nitzschia (Pseudo-nitzschia americana and Pseudo-nitzschia multiseries) for Helgoland Roads [13]. It is not feasible to routinely identify these species reliably, at least not in temporally highly resolved time series such as Helgoland Roads, and thus, in these time series they will continue to be recorded as an unnamed size class (or identified as Pseudonitzschia spp in a given size range). However, as at least $P$. multiseries is a domoic acid producer and has been reported from the North Sea, an effort should be made to regularly assess the presence of this species by periodic TEM surveys, with molecular identification methods $[37,38]$ and using toxin screenings.

The situation is different for Chaetoceros species where several species that can be identified in live or even Lugol-fixed samples, were recorded for the first time. Chaetoceros anastomosans for instance is a rather distinctive species, with intercalary setae that are fused by way of a 'bridge' several $\mu$ ms away from the valve pole. It is therefore unlikely to have been missed in the past. Taking this into account, and considering that quantitative counts are carried out at a very high, work-daily frequency, this record can be regarded as a true new record at Helgoland Roads. For the other two Chaetoceros species (Chaetoceros pseudocurvisetus and Chaetoceros lorenzianus), where there are similar species present in the Helgoland phytoplankton community with which they might have been confused, the situation is more complex. This is particularly true for Chaetoceros lorenzianus, which is morphologically variable, very similar in appearance to Chaetoceros decipiens and is only reliably identifiable if cyst formation has been observed. Varying degrees of fusion of the basal parts of adjacent intercalary setae was previously used to distinguish between taxa, but this is no longer regarded as a reliable taxonomic feature [39].
Chaetoceros lorenzianus is sometimes regarded as a warm water species but has a very broad distributional range (OBIS 2016). Blooms of a similar species, recorded as Chaetoceros cf. lorenzianus have been observed in the Baltic recently also in autumn [40].

Similarly C. pseudocurvisetus might be relatively easy to identify in broad girdle view but possibly not when viewed in narrow girdle view, where the characteristic aperture between valves is not visible. At Helgoland there are two species with a morphology similar to $C$. pseudocurvisetus namely $C$. debilis and $C$ curvisetus which also form curved chains with all setae pointing in the same direction towards the outside of the chain. It is therefore conceivable that C. pseudocurvisetus has previously been overlooked. C. pseudocurvisetus is regarded as a warm water species [17]. It has been recorded from the English channel and it was also found in Narragansett Bay [41, 42], interestingly also in September/October and in a similar assemblage to that found in Helgoland in autumn 2009.

We were only able to update this check-list with a combination of long-term observation and targeted semi-quantitative light microscopic surveys. These were mostly from one site so that no information about the rate of immigration (flux) of new species at Helgoland Roads is available. Since, in contrast to the taxonomic check-list of 2004 [7], we could not carry out systematic electron microscopic or culturing studies due to time constraints, it is also likely that many hitherto unreported taxa remain to be discovered. Particularly for large diatom genera such as Pseudo-nitzschia, Chaetoceros or Thalassiosira, more detailed studies using a range of techniques are clearly to be recommended to not miss new records and also to better characterize the true diversity of the existing assemblages. However, these are beyond the scope of highfrequency manual monitoring programmes such as that at Helgoland Roads LTER. Thalassiosira is a particularly good example as the species reported for Helgoland Roads result mostly from previous intensive culturing and microscopic studies [43]. In the current study, based mostly on light microscopy, only a small fraction of the overall species complement was recorded. This fact also shows that great care has to be taken in interpreting data based on these different methodologies, all of which have their own biases and represent different sampling efforts (e.g. in terms of the examined sample volume). Just as new records based on the use of different methodologies are not easily interpretable in terms of rates of immigrations or changing environmental conditions, the absence of species in a data set, even on time scales of years, cannot necessarily be considered a local extinction. 


\section{Conclusion}

High-frequency quantitative time-series such as Helgoland Roads provide an excellent insight into longterm dynamics in a system, but standard methodologies employed by such time series limit the taxonomic resolution of the resulting data sets. Techniques such as electron microscopy on the other hand, provide better resolution, but are more time consuming and expensive. They are therefore not often deployed routinely which limits their usability for the analysis of temporal trends. All techniques used here have their merits but the best results could be obtained by using a tiered approach with the core time series being augmented with additional surveys, either at regular intervals (e.g. seasonal SEM surveys) or topical surveys e.g. to investigate the presence of toxins and by molecular studies. However, this requires tight data management procedures to facilitate the integration of a diverse array of methodologies in joint analysis approaches (and to correctly identify their limitations). Data management needs to include links to both sample and taxonomic (inclusive of reference images) metadata as described for Helgoland Roads. Importantly, for this time series, data management and archival have been extended to images which are archived in the online repository planktonnet and linked to the respective numerical data sets in Pangaea. Such a procedure is clearly recommended as standard whenever new plankton taxa are reported for an area. Such images should be archived with standardized metadata (e.g. types of microscopes, magnifications, microscopy techniques) just as for any numerical parameters such as temperature or salinity. This will facilitate a reliable confirmation of a species record and ensure consistency. It is doubtful whether it would ever be possible to $100 \%$ harmonize different time series. However, with similar overall metadata standards it is at least possible to assess to which degree time series can be compared. Such rigorous procedures will become even more important in future as molecular surveys are increasingly incorporated into routine monitoring programmes, likely increasing the number of species in many regional species lists from hundreds to thousands of taxa [44].

\footnotetext{
Acknowledgements

The authors wish to thank the ship crews of the vessels Aade and Uthörn (past and present) without whom the regular, high quality and high frequency samplings for Helgoland Roads LTER could not be accomplished. We also thank Dr Urban Tillmann who confirmed the identity of Alexandrium ostenfeldii and Dr Adriana Zingone who confirmed Odontella logicruris. Thanks are also due to staff at the Friedrich Hustedt collection for use of their scanning electron microscope and their excellent support. The work was carried out in the context of AWI's PACES research programme (workpackage 2.1).
}

\section{Authors' contributions}

AK carried out the semi-quantitative and SEM surveys that led to the detection of nine of the taxa described here and wrote the manuscript including combining the species lists. SP organizes and manages the Time Series
Helgoland Roads and Transects in the German Bight.is responsible for carrying out the routine counts of Helgoland Roads samples and assembled records of Plagiolemma distortum from Helgoland Roads. She and KW also managed the original Helgoland Roads species list. AK also wrote the main body of the manuscript. UK has carried out quantitative counts of the Helgoland transect data that led to the detection of Dinophysis tripos and provided image material of the taxon. KW manages the Helgoland Roads LTER. All authors read and approved the final manuscript.

\section{Funding}

This work was funded by the Alfred-Wegener Institute Helmholtz Centre for Polar and Marine Research

\section{Availability of data and materials}

All image material is available in the planktonnet repository (http://planktonne t.awi.de), numerical quantitative data are regularly archived in the Pangaea repository (http://pangaea.de), semi-quantitative data will be published in open access in Pangaea as well.

Ethics approval and consent to participate

All authors have consented to participate.

\section{Competing interests}

The authors declare that they have no competing interests.

\section{Author details}

${ }^{1}$ Alfred-Wegener-Institute Helmholtz Centre for Polar and Marine Research, Biologische Anstalt Helgoland, Kurpromenade 201, 27498 Helgoland, Germany. ${ }^{2}$ Alfred-Wegener-Institute Helmholtz Centre for Polar and Marine Research, Wattenmeerstation Sylt, Hafenstraße 43, 25992 List/Sylt, Germany.

Received: 3 October 2018 Accepted: 6 September 2019

Published online: 08 October 2019

\section{References}

1. Wiltshire KH, Kraberg A, Bartsch I, Boersma M, Franke HD, Freund J, et al. Helgoland Roads: 45 years of change in the North Sea. Estuaries Coasts. 2010. https://doi.org/10.1007/s12237-009-9228-y.

2. Wiltshire KH, Boersma M, Carstens K, Kraberg AC, Peters S, Scharfe M. Control of phytoplankton in a shelf sea: determination of the main drivers based on the Helgoland Roads Time Series. J Sea Res. 2015;105:42-52.

3. Kraberg AC, Rodriguez N, Salewski CR. Historical phytoplankton data from Helgoland Roads: can they be linked to modern time series data? J Sea Res. 2015:101:51-8.

4. Callies U, Gaslikova L, Kapitza H, Scharfe M. German Bight residual current variability on a daily basis: principal components of multi-decadal barotropic simulations. Geo-Mar Lett. 2016. https://doi.org/10.1007/s0036 7-016-0466-2.

5. Voynova YG, Brix H, Petersen W, Scharfe M. Extreme flood impact on estuarine and coastal biogeochemistry: the 2013 elbe flood. Biogeosci Discuss. 2016. https://doi.org/10.5194/bg-2016-218.

6. Menden-Deuer S, Lessard EJ, Satterberg J. Effect of preservation on dinoflagellate and diatom cell volume and consequences for carbon biomass predictions. Mar Ecol Prog Ser. 2001;222:41-50

7. Hoppenrath M. A revised checklist of planktonic diatoms and dinoflagellates from Helgoland (North Sea, German Bight). Helgoland Mar Res. 2004;58:243-51.

8. Drebes $\mathrm{G}$, Elbrächter M. A checklist of planktonic diatoms and dinoflagellates from Helgoland and List (Sylt), German Bight. Bot Mar. 1976:19:75-83.

9. Lund JWG, Kipling C, Le Cren ED. The inverted microscope method of estimating algal numbers and the statistical basis of estimations by counting. Hydrobiologia. 1958;11:143-70.

10. Throndsen J. Preservation and storage. Phytoplankton Manual UNESCO. Paris: UNESCO Press; 1978. p. 69-74.

11. Hasle GR, Fryxell GA. Diatoms: cleaning and mounting for light and electron microscopy. Trans Am Microsc Soc. 1970;89:469-74.

12. Lundholm N, Hasle GR, Fryxell GA, Hargraves P. Morphology, phylogeny and taxonomy of species within the Pseudo-nitzschia americana 
complex (Bacillariophyceae) with descriptions of two new species, Pseudo-nitzschia brasiliana ans Pseudo-nitzschia linea. J Phycol. 2002;41:480-97.

13. Bresnan E, Kraberg AC, Fraser S, Brown L, Hughes S, Wiltshire KH. Diversity and seasonality of Pseudo-nitzschia (Peragallo) at two North Sea time series monitoring sites. Helgoland Mar Res. 2015;69:193-204.

14. Costello MJ, Bouchet P, Boxshall G, Fauchald K, Gordon D, Hoeksema BW, et al. Global coordination and standardisation in marine biodiversity through the World Register of Marine Species (WoRMS) and related databases. PLoS ONE. 2013;8:20.

15. Zingone A, Harrison PJ, Kraberg AC, Lehtinen S, McQuatters-Gollop A, O'Brien T, et al. Increasing the quality, comprability and accessibility of phytoplankton species composition time-series data. Estuar Coast Shelf Sci. 2015;162:151-60.

16. Hoban MA. Biddulphioid diatoms III: morphology and taxonomy of Odontella aurita and Odontella longicruris (Bacillariophyta, Bacillariophytina, Mediophyceae) with comments on the sexual reproduction of the latter. Nova Hedwigia. 2008;Suppl. 133:47-65.

17. Tomas CR. Identifying marine phytoplankton. San Diego: Academic press; 1997. p. 858.

18. Lavigne AS, Sunesen I, Sar EA. Morphological, taxonomic and nomenclatural analysis of species of Odontella, Trieres and Zygoceros (Triceratiaceae, Bacillariophyta) from Anegada Bay (Province of Buenos Aires, Argentina). Diatom Res. 2015;30:307-31.

19. Kühn SF, Klein G, Halliger H, Hargraves P, Medlin LK. A new diatom, Mediopyxis helysia gen. nov. and sp. nov. (Mediophyceae) from the North Sea and the Gulf of Maine as determined from morphological and phylogenetic characteristics. Beiheft zur Nova Hedwigia. 2006;130:307-24.

20. Kraberg A, Carstens K, Tilly K, Wiltshire KH. The diatom Mediopyxis helysia at Helgoland Roads: a success story? Helgoland Mar Res. 2012;66:463-8.

21. Hoppenrath $M$, Elbrächter M and Drebes G. Marine Phytoplankton: Selected microphytoplankton species from the North Sea around Helgoland and Sylt. Kleine Senckenberg Reihe 49. Stuttgart. E. Schweizerbart'sche Verlagsbuchhandlung. 2009. 264. 264

22. Loebl M, van Beusekom JJE, Philippart CM. No microzooplankton grazing during a Mediopyxis helysia dominated diatom bloom. J Sea Res. 2012;82:80-5.

23. Hasle GR. Pseudo-nitzschia pungens and Pseudo-nitzschia multiseries (Bacillariphyceae); nomenclatural history, morphology and distribution. J Phycol. 1995;31:428-35.

24. Kaczmarska I, Martin JL, Ehrmann JM, LeGresley MM. Pseudo-nitzschia species population dynamics in the Quoddy region, Bay of Fundy. Harmful Algae. 2007;6:861-74.

25. Kaczmarska I, LeGresley MM, Martin JL, Ehrmann J. Diversity of the diatom genus Pseudo-nitzschia Peragallo in the Quoddy Region of the Bay of Fundy, Canada. Harmful Algae. 2005;4:1-19.

26. Hasle GR. Are most of the domoic acid-producing species of the diatom genus Pseudo-nitzschia cosmopolites? Harmful Algae. 2002;1:137-46.

27. Ellegaard M, Godhe A, Harnstroem K, McQuoid MR. The species concept in a marine diatom: LSU rDNA-based phylogenetic differenctiation in Skeletonema marinoi/dohrnii (Bacillariophyceae) is not reflected in morphology. Phycologia. 2008;47:156-67.

28. Sarno D, Kooistra WHCF, Medlin LK, Percopo I, Zingone A. Diversity in the genus Skeletonema (Bacillariophyceae). II An assessment of the taxonomy of S. costatum - like species with the description of four new species. J. Phycol. 2005;41:151-76.

29. Kooistra HCF, Sarno D, Balzano S, Gu H, Anderson RA, Zingone A. Global diversity and biogeography of Skeletonema species (Bacillariophyta). Protist. 2008;159:177-93.
30. Kremp A, Godhe A, Egardt J, Dupont S, Suikkanen S, Casablanca S, Penna A. Intraspecific variability in the response of bloom-forming marine microalgae to changed climate conditions. Ecol Evol. 2012;2:1195-207.

31. Nezan E, Bilien G, Boulben S, Mertens KN, Chomerat N. Desription and phylogenetic position of Plagiolemma distortum sp. nov., a new raphid diatom (Bacillariophyceae) from French coastal waters. Diatom Research. 2018. https://www.tandfonline.com/doi/full/10.1080/02692 49X.2018.1468359.

32. Kraberg AC, Widdicombe $C$, Beckett R, Rick J, Rooks P, van Wezel R. Further records of a new diatom species in the English Channel and North Sea: the importance of image-referenced data. Mar Biodivers Rec. 2018. https ://doi.org/10.1186/s41200-018-0155-0.

33. Larsen J, Moestrup $\varnothing$. Potentially toxic phytoplankton. 2. Genus Dinophysis. ICES Identification leaflet for plankton 1992;No 180:12.

34. Cembella AD, Lewis NI, Quilliam MA. The marine dinoflagellate Alexandrium ostenfeldii (Dinophyceae) as the causative organism of spirolide shellfish toxins. Phycologia. 2000;39:67-74.

35. Gribble KE, Kaefer BA, Quilliam MA, Cembella AD, Kulis DM, Manahan A, Anderson DM. Distribution and toxicity of Alexandrium ostenfeldii (Dinophyceae) in the Gulf of Main, USA. Eur J Phycol. 2005;52:2745-63.

36. Brown L, Bresnan E, Graham J, Lacaze JP, Turrell E, Collins C. Distribution, diversity and toxin composition of the genus Alexandrium (Dinophyceae) in Scottish waters. Eur J Phycol. 2010;45:375-93.

37. Diercks S, Metfies K, Medlin LK. Molecular probe sets for the detection of toxic algae for use in sandwich hybridization formats. J Plankton Res. 2008;30:439-48.

38. Metfies K, Schroeder F, Hessel J, Wollschläger J, Micheller S, Wolf C, et al. High-resolution monitoring of marine protists based on an observation strategy integrating automated on-board filtration and molecular analyses. Ocean Sci. 2016;12:1237-47.

39. Li Y, Boonprakob A, Gaonkar CC, Kooistra WCF, Lange KB, Chen Z, et al. Diversity in the globally distributed diatom genus Chaetoceros (Bacillariophyceae): Three new species from warm-temperate waters. PLOS ONE. 2017. https://doi.org/10.1371/journal.pone.0168887.

40. Kownacka J, Edler L, Gromisz S, Lotocka M, Olenina I, Ostrowska M, Piwosz K. Non-indigenous species Chaetoceros cf. lorenzianus Grunow 1863-a new, predominant component of autumn phytoplankton in the southern Baltic Sea. Estuar Coast Shelf S. 2013;119:101-11.

41. Hendey I. An introductory account of the smaller algae of British Coastal waters. London: Her Majesty's Stationary office; 1964. p. 317.

42. Rines JEB, Hargraves P. The seasonal distribution of the marine diatom genus Chaetoceros Ehr. in Narragansett Bay, Rhode Island (1981-1982). J Plankton Res. 1987;9:917-33.

43. Hoppenrath M, Beszteri B, Drebes G, Halliger H, Van Beusekom JEE, Janisch S, Wiltshire KH. Thalassiosira species (Bacillariophyceae, Thalassiosirales) in the North Sea at Helgoland (German Bight) and Sylt (North Frisian Wadden Sea) - a first approach to assessing diversity. Eur J Phycol. 2007;42:271-88.

44. Stern R, Kraberg AC, Bresnan E, Kooistra HCF, Lovejoy C, Montresor $\mathrm{M}$, et al. Molecular analyses of protists in long-term observation programmes - current status and future perspectives. J Plankton Res. 2018;40:519-36.

\section{Publisher's Note}

Springer Nature remains neutral with regard to jurisdictional claims in published maps and institutional affiliations. 